\title{
IMPLEMENTASI PENGGUNAAN BAHASA INGGRIS PADA PEMBELAJARAN PAI DINIYAH ULYA KELAS 4 DENGAN METODE COLLABORATIVE LEARNING DI PONDOK PESANTREN MIFTAHUL HUDA AL-AZHAR CITANGKOLO
}

\author{
Yudi Kusmayadi \\ STAI Miftahul Huda Al-Azhar Banjar \\ yudi.kusmayadi20@yahoo.co.id
}

\begin{abstract}
This research has a background that the era of globalization raises the community's need for international schools that have the concepts and systems needed for international standard schools that actually implement the international system. Not only limited to the cover or international appearance, but the content and purpose according to the label displayed. So that it can answer people's anxiety. This study aims to describe the implementation of the use of English in PAI learning in diniyah ulya grade 4 by using the Collaborative Learning method at Miftahul Huda Al-Azhar Islamic Boarding School in Citangkolo Banjar,

Including the preparation, implementation, and evaluation of PAI learning, advantages and disadvantages, obstacles and solutions for Implementation of English using English in PAI learning in diniyah ulya grade 4 by using Collaborative Learning method in Islamic boarding school Miftahul Huda al Azhar Citangkolo Banjar City The results of this study are (1) Implementation of the use of English in PAI learning in grade 4th grade ulya Madrasah Ali Miftahul Huda Al Azhar Citangkolo Banjar as a whole is in accordance with the guidelines of learning programs with the use of foreign languages. language. (2) the benefits of implementing the use of English motivate teachers and students to master English better, foster greater self-confidence in teachers and students, students avoid speaking improperly /


disrespectfully, increasing students' abilities or skills (abilities) in English, add teacher insight. Deficiencies in the form of time effectiveness (3) constraints in the form of teacher recruitment, standardization of the English language ability of PAI teachers, building madrasa culture, mastering English that is owned by teachers and students. Solutions in the form of conducting English learning for teachers and students, supplementary learning for students in the afternoon, conducting training for teachers, delegating PAI teachers to build madrasa culture, making corrections to lesson plans, and teaching practices (Micro Teaching), controlling language.

Keywords: Implementation, English, PAI Learning.

\section{A. PENDAHULUAN}

Arus globalisasi sekarang ini telah merambah ke seluruh penjuru dunia, tidak terkecuali ke Indonesia. Munculnya era globalisasi, tidak hanya memberikan dampak positif, namun juga memunculkan dampak negatif bagi masyarakat luas. Globalisasi secara tidak langsung telah memberikan tuntutan- tuntutan yang memerlukan perhatian yang sungguh-sungguh dari seluruh lapisan masyarakat. Adanya era globalisasi, masyarakat secara tidak langsung diharuskan untuk menghadapi beberapa tantangan-tantangan diantaranya, pertahanan diri untuk menghadapi fenomena global, kesiapan diri untuk menghadapi era kompetisi, serta kesiapan untuk meningkatkan kualitas diri sebagai sumber daya manusia yang memenuhi syarat.

Globalisasi telah memberikan dampak hampir di seluruh bidang, diantaranya adalah pada komunikasi, ekonomi, sosial, dan lain sebagainya, tidak terkecuali pendidikan. Tantangan pertama yang harus dihadapi oleh dunia pendidikan adalah kualitas, dimana adanya era globalisasi pada dasarnya telah muncul pula era kompetisi, berbicara tentang kompetisi adalah sama halnya seperti berbicara tentang keunggulan

Adanya peningkatan kualitas dan persaingan pada bidang pendidikan, sekolah-sekolah berlomba untuk menjadi sebuah lembaga 
pendidikan yang mumpuni serta berkualitas sesuai dengan kebutuhan global, diantaranya terbukti dengan munculnya sekolah-sekolah yang memiliki sistem dengan standar internasional yang menyediakan fasilitas-fasilitas khusus, baik dari segi sarana dan prasarana, kegiatan pembelajaran, hingga tenaga pendidik

Di Indonesia Bahasa Inggris adalah satu-satunya bahasa asing yang wajib dipelajari mulai dari tingkat SD / Madrasah hingga perguruan tinggi. Walaupun sudah dipelajari dalam jangka waktu yang sudah cukup lama tapi banyak siswa yang mengalami permasalahan dalam mempelajari Bahasa Inggris. Mereka mengalami kesulitan dalam berbicara, mendengar, membaca dan menulis dalam Bahasa Inggris. Hal ini diakibatkan kurangnya rasa percaya diri dalam berbicara Bahasa Inggris dan kekhawatiran melakukan kesalahan dalam menerapkan tata bahasa, menyebutkan kosakata, pelafalan dan lain-lain. Dilihat dari sisi Ilmu bahasa atau linguistik, kesulitan para siswa Indonesia dalam mempelajari bahasa Inggris juga Karena disebabkan oleh perbedaan struktur antara bahasa Inggris dan bahasa Indonesia baik dalam tataran Sintaksis, Morpologis, Ponologis, Semantik dan lain-lain.

Dari sisi pedagogik kesulitan siswa belajar bahasa Inggris karena di Indonesia masih banyak guru yang menggunakan metode konvensional atau menggunakan Bahasa Indonesia sebagai bahasa pengantarnya sehingga siswa hanya sedikit saja mendapatkan pengalaman dalam mendengarkan Bahasa Inggris, akibatnya siswa tidak memiliki sumber yang cukup untuk mereka berbicara dalam Bahasa Inggris

Dari sekian banyak sekolah yang menghadapi kesulitan dalam mempelajari bahasa Inggris salah satunya adalah pesantren yang ada di kota Banjar yaitu pesantren Miftahul Huda Al-Azhar Citangkolo . Di Ponpes ini para siswa diajarkan bahasa Inggris dan diharapkan untuk mampu membaca teks dalam bahasa Inggris khususnya diniyah kelas 4 . Namun, berdasarkan informasi yang diperoleh oleh tim pengabdian saat survey awal dari guru bahwa harapan itu belum terwujud. Masih banyak sekali siswa yang kesulitan memahami teks berbahasa Inggris. Mungkin hal ini terjadi karena bahasa Inggris masih baru bagi mereka sehingga mereka kekurangan pengetahuan akan tatabahasa Inggris yang 
memadai, kurangnya penguasaan kosakata, kurang percaya diri, takut salah, lingkungan yag kurang mendukung penggunaan bahasa Inggris, dan lain-lain.

Untuk mengatasi kesulitan tersebut, seorang guru bahasa Inggris hendaknya jeli untuk memilih metode mengajar yang baik. Ada beberapa metode yang bisa digunakan dalam proses kegiatan belajarmengajar Bahasa Inggris di kelas. Metode yang digunakan sebaiknya membiarkan siswa untuk menggunakan Bahasa Inggris se-natural mungkindan menciptakan suasana aktif dan adanya kerjasama antar siswa. Salah satu metode tersebu adalah metode Collaborative Learning

Metode ini adalah pengelompokkan siswa dalam beberapa kelompok kecil sehingga mereka dapat berdiskusi dan bekerjasama untuk memecahkan masalah dalam Bahasa Inggris. Namun metode ini dapat menimbulkan masalah lain terutama jika jumlah siswa yang banyak sehingga guru menghadapi kesulitan dalam mengatur proses belajar siswa

\section{METODOLOGI PENELITIAN}

Dalam penelitian ini digunakan pendekatan penelitian tindakan kelas (classroom action research) yang bertipe penelitian tindakan kemitraan atau penelitian kolaboration. Penelitian ini menggunakan sample kelas 4 di diniyah yang berada di lingkup pondok pesantren Miftahul Huda Al-Azhar. Ada dua pertimbangan digunakannya penelitian tindakan kelas. Pertama, penelitian tindakan kelas merupakan suatu metode dan proses untuk menjembatani antara teori dan praktik. Kedua, penelitian tindakan dapat mengkaji permasalahan secara praktis, bersifat situasional dan kontekstual, serta bertujuan menentukan tindakan yang tepat dalam rangka memecahkan masalah yang dihadapi (Elliot, 1991:70-71; Natawidaja, 1997:3).

Penelitian tindakan kelas ini memiliki beberapa kegunaan, yakni untuk : • Menaggulangi masalah atau kesulitan dalam pendidikan dan pengajaran yang dihadapi guru, terutama berkenaan dengan masalah pembelajaran; - Memberikan pedoman bagi guru dan administrator pendidikan di sekolah untuk memperbaiki dan meningkatkan mutu kinerja mereka; • Memasukkan unsur-unsur pembaharuan dalam proses 
pembelajaran; • Membangun dan meningkatkan mutu komunikasi dan interaksi antara para praktisi ( dalam hal ini, guru ) dengan penelitian akademis.

Tindakan kelas yang dilakukan dalam pengadian ini berupa penerapan Model Collaborative Learning di dalam pembelajaran membaca pemahaman bahasa Inggris dengan pengendalian prates dan postes (pre-post test control). Kegiatan tindakan kelas ini dilakukan sebanyak tujuh kali siklus. Setiap siklus berpolakan lima tahap kegiatan, yakni (1) perencanaan (2) pelaksanaan, (3) observasi, (4) refleksi, dan (5) revesi.

\section{PEMBAHASAN}

\section{Landasan Teori}

a. Implementasi Penggunaan Bahasa Inggris

a. Pengertian pentingnya penggunaan bahasa Inggris

Menurut KBBI kata implementasi berarti penerapan atau pelaksanaan. Sedangkan penggunaan berarti pemakaian. ${ }^{13}$ Mengutip dari buku yang ditulis oleh Prof. Dr. H. E. Mulyasa dalam Oxford Learner's Dictionary dikemukakan bahwa implementasi adalah "put something into effect (penerapan sesuatu yang memberikan dampak atau efek). Bahasa berfungsi sebagai alat untuk berpikir dan belajar. Dengan adanya bahasa memungkinkan manusia untuk berpikir secara abstrak. Manusia dapat memikirkan sesuatu meskipun objek yang dipikirkan itu tidak berada tidak dekat. Dengan simbol-simbol bahasa yang abstrak dapat memunculkan pemikiran sesuatu secara terus menerus dan kemudian mewariskan pegalamannya itu kepada generasi-generasi berikutnya. Seseorang dapat pula mengkomunikasikan sesuatu yang dipikirkan dan dapat pula belajar sesuatu dari orang lain.

- Pembelajaran Pendidikan Agama Islam

1. Pengertian Pembelajaran

Secara istilah, pembelajaran diartikan oleh beberapa pakar sebagai berikut, Ahmad Rohani dan Abu Ahmadi mengartikan pembelajaran sebagai suatu aktivitas (proses belajar mengajar) yang sistematis dan sistemik yang terdiri dari berbagai komponen, antara satu 
komponen pengajaran dengan lainnya saling tergantung dan sifatnya tidak parsial, komplementer dan berkesinambungan Menurut Dimyati dan Mudjiono pembelajaran adalah kegiatan guru secara terprogram dalam desain instruksional, untuk membuat siswa belajar secara aktif, yang menekankan pada penyediaan sumber belajar

Dalam Undang-Undang No. 20 Tahun 2003 Tentang Sistem Pendidikan Nasional pasal 1 ayat 20 dinyatakan bahwa "Pembelajaran adalah Proses interaksi peserta didik dengan pendidik dan sumber belajar pada suatu lingkungan belajar

Dari beberapa pendapat diatas dapat disimpulkan bahwasannya pembelajaran adalah usaha sadar yang dilakukan oleh guru untuk membuat siswa belajar sehingga terjadi terjadi sebuah interaksi antara pendidik dan peserta didik untuk tujuan adanya perubahan tingkah laku menjadi lebih baik pada peserta didik

1. Faktor-faktor yang Mempengaruhi Proses Pembelajaran

Masalah interaksi belajar mengajar merupakan masalah yang kompleks karena melibatkan berbagai faktor yang saling terkait satu sama lain. Dari sekian banyak faktor yang mempengaruhi proses dan hasil interaksi belajar mengajar terdapat dua faktor yang sangat menentukan yaitu faktor guru sebagai subjek pembelajaran dan faktor peserta didik sebagai objek pembelajaran. Tanpa adanya faktor guru dan peserta didik dengan berbagai potensi kognitif, afektif, dan psikomotorik yang dimiliki tidak mungkin proses interaksi belajar mengajar dikelas atau ditempat lain dapat berlangsung dengan baik. Namun pengaruh berbagai faktor lain tidak boleh diabaikan, misalnya faktor media dan instrument pembelajaran, fasilitas belajar, infrastruktur sekolah, fasilitas laboratorium, manajemen sekolah, sistem pembelajaran dan evaluasi, kurikulum, metode, dan strategi pembelajaran. Kesemua faktor-faktor tersebut dengan pendekatan berkontribusi berarti dalam meningkatkan kualitas dan hasil interaksi belajar mengajar di kelas dan tempat belajar lainnya.

\section{Pendidikan Agama Islam}

Pasal 39 ayat 2 di tegaskan bahwa isi kurikulum setiap jenis, jalur dan jenjang pendidikan wajib memuat : (a) pendidikan pancasila, 
(b) pendidikan agama (c) Pendidikan kewarganegaraan. Dari isyarat pasal tersebut dapat dipahami bahwa bidang studi pendidikan agama, baik agama Islam maupun agama lainnya meupakan komponen dasar/wajib dalam kurikulum pendidikan nasional.

Pendidikan agama Islam adalah usaha sadar atau secara di sengaja untuk menyiapkan siswa dalam meyakini, memahami, menghayati, dan mengamalkan agama Islam melalui kegiatan bimbingan, pengarahan, dan latihan dengan memperhatikan tuntutan untuk menghormati agama lain dalam hubungan kerukunan antar umat beragama dalam masyarakat untuk mewujudkan kesatuan nasional.

\section{Tujuan Pendidikan Agama Islam}

Secara umum pendidikan agama Islam bertujuan untuk meningkatkan keimanan, pemahaman, penghayatan, serta pengamalan peserta didik tentang agama Islam, menjadi manusia muslim yang beriman dan bertaqwa kepada Allah SWT serta berakhlak mulia.

Materi Pendidikan Agama Islam

Sebagaimana diketahui, bahwa inti ajaran pokok Islam meliputi: masalah keimanan (aqidah), masalah keIslaman (syariah) dan masalah ihsan (akhlak).

\section{Aqidah}

Aqidah adalah bersifat i"tikad batin, mengajarkan keesaan Allah, Esa sebagai Tuhan yang mencipta, mengatur, dan meniadakan alam ini.

Syarieah

Syariah adalah berhubungan dengan amal lahir dalam rangka mentaati peraturan dan hukum Tuhan, guna mengatur hubungan antara manusia dengan Tuhan dan mengatur pergaulan hidup dan kehidupan manusia.

\section{Akhlak}

Akhlak adalah suatu amalan yang bersifat pelengkap penyempurna.

Bagi kedua amal di atas dan yang mengajarkan tentang tata cara pergaulan hidup manusia. Dari tiga inti ajaran pokok lahirlah beberapa keilmuan Agama yaitu: Ilmu Tauhid, Ilmu Fiqih dan Ilmu Akhlak. Ketiga ilmu pokok Agama ini kemudian dilengkapi dengan pembahasan dasar hukum Islam yaitu Al-Qur"an dan Al-Hadits serta ditambah 
lagi dengan Sejarah Islam (Tarikh), hal ini sekaligus menggambarkan bahwa ruang lingkup Pendidikan Agama Islam mencakup perwujudan keserasian, keselarasan, dan keseimbangan hubungan manusia dengan Allah Swt, diri sendiri, sesama manusia, makhluk lainnya maupun lingkungannya (Hablun minallah wa hablun minannas).

Metode Pembelajaran Pendidikan Agama Islam

Metode adalah cara yang digunakan tenaga pendidik dan peserta didik dalam proses belajar mengajar. Metode yang digunakan untuk menerapkan

kurikulum pendidikan agama Islam tidak jauh berbeda dengan metode yang digunakan pendidikan umum. Ada dua alasan dalam menggunakan metode untuk medesain kurikulum PAI agar menarik, bermanfaat, dan relevan dengan isi dan konteks sosial, yaitu:

Landasan motivasional untuk memupuk sifat individu peserta didik agar menerima ajaran agama dan sekaligus bertanggung jawab terhadap pengalamannya dalam kehidupan sehari-hari.

Landasan moral yaitu tertanamnya nilai keagamaan dan keyakinan peserta didik sehingga perbuatannya selalu mengacu pada isi, jiwa dan akal semangat akhlakul mahmudah. ${ }^{32}$

Pendekatan Pembelajaran Pendidikan Agama Islam

Pendekatan yang digunakan dalam pembelajaran pendidikan agama Islam adalah:

Keimanan, yaitu pendekatan yang memberi peluang kepada peserta didik untuk mengembangkan pemahaman adanya Tuhan sebagai sumber kehidupan makhluk di dunia.

Pengalaman, yaitu memberikan kesempatan kepada peserta didik untuk mempraktekkan dan merasakan hasil-hasil pengalaman ibadah dan akhlak dalam mengahadapi tugas-tugas dan masalah dalam kehidupan.

Pembiasaan, yaitu memberikan kesempatan kepada siswa didik untuk membiasakan sikap dan perilaku yang sesuai dengan ajaran agama Islam dan budaya bangsa dalam mengahadapi masalah kehidupan.

Rasional, yaitu usaha memeberikan peranan pada rasio peserta didik dalam memahami dan membedakan berbagai bahan ajar dalam 
standar materi serta kaitannya dengan perilaku baik dan buruk dalam kehidupan sehari-hari.

Emosional, yaitu upaya menggugah perasaan (emosi) peserta didik dalam menghayati perilaku yang sesuai dengan ajaran agama dan budaya bangsa.

Fungsional, yaitu menyajikan bentuk semua standar materi, (AlQur"an, keimanan, akhlak, fiqh/ibadah, dan tarikh), dari segi manfaatnya bagi peserta didik dalam kehidupan sehari-hari dalam arti luas.

Keteladanan, yaitu menjadikan figur guru agama dan non agama serta petugas sekolah lainnya maupun orang tua peserta didik, sebagai cermin manusia yang berkepribadian.

Evaluasi Pendidikan Agama Islam

Evaluasi adalah suatu tindakan atau proses menentukan nilai segala sesuatu dalam akifitas pendidikan, baik menyangkut materi, guru, siswa, serta aspek pendukung lainnya untuk mengukur sejauh mana tujuan yang telah ditetapkan itu tercapai guna melakukan perbaikanperbaikan. Evaluasi kurikulum pendidikan agama Islam tidak hanya diukur dengan alat atau instrumen test tuli, melainkan dapat dilihat dari segi performance akhlak dan tindakannya. Evaluasi dari pendidikan agama Islam lebih mudah dilihat dari segi afektif dan psikomotornya dari pada kognitifnya.

Dari beberapa pemamparan diatas, dapat disimpulkan bahwasannya Implementasi penggunaan bahasa Inggris pada pembelajaran PAI adalah penerapan penggunaan/pemakaian bahasa Inggris secara penuh sebagai bahasa pengantar dalam keseluruhan kegiatan pembelajaran PAI dari persiapan pembelajaran, pelaksanaan, serta evaluasi, baik secara verbal dan tertulis, serta secara aktif maupun pasif.

\section{Madrasah Diniyah}

Madrasah Diniyah adalah lembaga pendidikan dan pengajaran Agama Islam jalur luar sekolah. Lembaga ini dikenal bersamaan dengan penyebaran Agama Islam di Indonesia. Pada masa penjajahan, hampir semua desa di seluruh pelosok tanah air yang ada penduduknya yang 
beragama Islam terdapat Madrasah Diniyah dengan berbagai nama dan bentuk, seperti Pengajian Anakanak, Sekolah Kitab, Sekolah Agama, Sistem Surau, Rangkang dan lainlain. Penyelenggaraan madrasah diniyah biasanya mendapat bantuan dari rajaraja atau sultan setempat.

Sesuai dengan perkembangan zaman dan tuntutan kebutuhan, ideide pembaharuan pendidikan Agama, Madrasah Diniyah pun ikut serta mengalami pembaharuan. Beberapa organisasi penyelenggara Madrasah Diniyah melakukan modifikasi kurikulum bukan saja kurikulum inti yang dikeluarkan kemeterian Agama, melainkan pula kurikulum lokal pun terus dibenahi sesuai dengan prinsip dan karakteristik lingkungannya.

Setelah Indonesia merdeka dan berdiri Departemen Agama (dahulu) Kementerian Agama (sekarang) penyelenggaraan madrasah diniyah mendapat subsidi dan bimbingan dari departemen Agama. Namun karena berdirinya Madrasah Diniyah memiliki latar belakang tersendiri dan kebanyakan didirikan atas usaha perorangan yang sematamata untuk ibadah, maka sistem dan penyelenggaraannya bergantung pada latar belakang pendiri dan pengasuhnya, sehingga pertumbuhan madrasah diniyah di Indonesia mengalami banyak corak dan ragamnya.

\section{Collaborative Learning}

Menurut Smith \& MacGregor (1992), "Collaborative Learning" adalah satu istilah untuk suatu jenis pendekatan pendidikan yang meliputi penggabungan karya/usaha intelektual siswa, atau siswa bersama dengan guru. Biasanya, siswa bekerja dalam 2 atau lebih kelompok, saling mencari pemahaman, penyelesaian, atau arti, atau membentuk suatu produk/hasil. Kegiatan dalam Collaborative Learningbermacam-macam,

tetapi pada dasarnya berpusat pada eksplorasi siswa atau aplikasi dari bagian materi, dan bukan hanya ceramah dari guru. Collaborative Learning menggambarkan suatu perubahan yang signifikan dari pembelajaran yang berpusat pada guru menjadi pembelajaran yang berpusat pada siswa. Dalam Collaborative Learning, penekanannya 
Thorigotuna | Jurnal Pendidikan Islam

adalah pada diskusi siswa dan keaktifan dalam bekerja dengan materi yang telah disediakan.

. Gunawan (2003 : 198 - 199) lebih menspesifikkan gambaran tentang proses belajar secara kolaborasi atau Collaborative Learning. Menurutnya, penekanan Collaborative Learning bukan hanya sekadar bekerja sama dalam suatu kelompok tetapi lebih kepada suatu proses pembelajaran yang melibatkan proses komunikasi secara utuh dan adil di dalam kelas. Proses tersebut meliputi :

1.Bagaimana guru berkomunikasi dengan murid dalam kaitannya dengan informasi yang akan diajarkan dan bagaimana kriteria penilaian?

Bagaimana murid itu berkomunikasi dengan guru dengan guru dan dengan murid lainnya?

1. Apakah komunikasi di kelas adalah komunikasi satu arah, dua arah, atau multi arah?

1. Apakah komunikasi dalam bentuk tulisan, ucapan, atau sentuhan dan peragaan?

Menurut Kemp dalam Hirschy (2003), Collaborative Learning itu meliputi kemampuan sosial dan kemampuan pembelajaran. Ini menggabungkan 3 konsep, yaitu tanggungjawab individu (individual accountability), keuntungan kelompok (group benefit), dan pencapaian kesuksesan yang sama (equal achievement of success). Tujuan dari Collaborative Learningadalah meningkatkan interaksi siswa dalam memahami suatu tugas.

Kelebihan dan Kekurangan Collaborative Learning

a. Kelebihan

- Siswa belajar bermusyawarah

- Siswa belajar menghargai pendapat orang lain

- Dapat mengembangkan cara berpikir kritis dan rasional

- Dapat memupuk rasa kerja sama

- Adanya persaingan yang sehat

b. Kelemahan

- Pendapat serta pertanyaan siswa dapat menyimpang dari pokok persoalan.

- Membutuhkan waktu cukup banyak. 
- Adanya sifat-sifat pribadi yang ingin menonjolkan diri atau sebaliknya yang lemah merasa rendah diri dan selalu tergantung pada orang lain.

- Kebulatan atau kesimpulan bahan kadang sukar dicapai.

\section{Pondok Pesantren}

Dunia pondok pesantren merupakan lembaga pendidikan islam dimana didalamnya belajar ilmu agama. Seperti kitab-kitab kalasik, dan kitab-kitab syariat lainnya. Dan pada perkembangannya pondok pesantren mengalami kemajuan yang tidak hanya berkutat pada pengkajian agama atau kitab-kitab klasik, Melaikan pengajaran tentang ilmu-ilmu pengetahuan umum modern yang sudah diperkenalkan termasuk teknologi.

Adanya berbagai macam bidang kemajuan keilmuan yang diadopsi oleh pesantren tetap menjadi perhatian dan pengawasan pesantren, karena hal ini perlu dilakukan oleh pesantren untuk mengantisipasi adanya masalah, utamanya dalam menyaring dampak negatif keilmuan-keilmuan modern yang akan merusak citra pondok pesantren itu sendiri, sehingga pemprogramannyapun dibatasi dan hanya sebagai kepentingan tertentu saja.

Sehubungan dengan hal tersebut pondok pesantren tidak hanya sebagai wadah pengkajian ilmu agama islam melainkan juga sebagai wahana pemberdaya umat. hal ini dikarenakan kemajuan pondok pesantren dari masa ke masa, Seperti yang kita ketahui bersama bahwa visi dan misi pondok pesantren bukanlah rahasia publik akan tetapi fungsi maupun peran pesantren memanglah benar sebagai pemberdaya umat baik dari berbagai bidang seperti; syi'ar keagamaan (dakwah) pengkajian kitab, sejarah, seni budaya, ilmu pengatahuan alam, astronomi, teknologi, olahraga, politik, bidang ekonomi, dan lain sebagainya.

Pondok pesantren sebagai lembaga pendidikan dan pusat penyebaran agama Islam lahir dan berkembang semenjak masa-masa permulaan kedatangan agama Islam di negeri kita. Sebagaiman kita semua mengetahuinya bahwa pondok pesantren sebagai lembaga pendidikan Islam yang tertua di Indonesia telah menunjukan 
kemampuanya dalam mencetak kader-kader ulama dan turut berjasa dalam meningkatkan kesejahteraan masyarakat Indonesia.

Sebagaian pemerhati mengatakan bahwa istilah pondok pesantren berasal dari kata funduk dari Bahasa Arab yang artinya hotel atau rumah penginapan. Akan tetapi pondok di dalam pesantren di Indonesia, khususnya di pulau Jawa, lebih mirip dengan pemondokan dalam lingkungan padepokan, yaitu perumahan sederhana yang di petak-petak dan beberapa kamar-kamar merupakan asrama bagi para santri atau cantrik (sebutan peserta didik di padepokan). Dan keseluruhan lingkungan masyarakat di mana tempat para santri itu mukim dan menuntut ilmu, maka disebut pesantren

\section{Hasil Penelitian}

Bagian ini akan mencoba untuk membahas kembali beberapa hal yang telah ditemukan pada penelitian pada pembelajaran PAI di diniyah kelas 4 di Pesantren Al- Azhar Citangkolo Kota Banjar: Pertama, Hasil tes awal menunjukan kemampuan berbahasa Inggris khususnya kemampuan membaca pemahaman teks diskriptif siswa masih sangat rendah yaitu rata-rata hanya 5,5 . Saat bertemu dengan para siswa untuk pertama kali diketahui bahwa metode mengajar yang digunakan oleh guru juga masih tradisional yaitu hanya menggunakan buku teks dan LKS. Peran guru juga cenderung sangat dominan dengan kata lain siswa cenderung pasif. Para siswa juga cenderung bekerja individual kalaupun ada kerjasama hanya dengan teman sebelah. Kedua, pada pelaksanaan penerapan metode Collaborative Learning yang berlangsung pada pengabdian hari kedua sampai ke delapan yang artinya ada tujuh siklus terjadi perubahan kebiasaan siswa yang tadinya cenderung ribut menjadi lebih teratur. Para siswa yang juga awalnya sangat tidak biasa bekerja sama pelan-pelan mulai biasa dan akhirnya sangat terampil bekerja sama. Siswa juga cenderung sangat akfit baik bertanya maupun dalam menyampaikan ide dan pendapat. Ketiga, peran guru/instruktur juga mengalami perubahan yang cukup signifikant jika di siklussiklus awal dia cenderung sangat dominan mengatur kelas, maka di siklus-siklus akhir sangat bebas karena dia berhasil mengaktifkan siswa dalam bekerjasama sehingga siswa cenderung mandiri tanpa banyak dibantu. 
Keempat, terjadi peningkatan kemampuan berbahasa Inggris khususnya kemampuan membaca teks diskriptif para siswa yang cukup signifikant setelah mendapatkan pembelajaran dengan menggunakan metode Collaborative Learning selama tujuh siklus dimana nilai rata-rata tes awal hanya 5,5 menjadi 7,5 pada tes akhir hingga ada peningkatan 2,0. Dengan kata lain Pelatihan Peningkatan Kemampuan Berbahasa Inggris dengan metode Collaborative learning di siswa kelas 4 diniyah Pondok Pesantren Miftahul Huda Al-Azhar Citangkolo Kota Banjar

\section{PENUTUP}

Dari hasil penelitian dapat di-simpulkan bahwa Berdasarkan rumusan masalah dan tujuan penelitian pengabdian yang telah dikemukakan terdahulu pada bab I, maka dapatdismpulkan beberapa hal pokok yan g berkaitan dengan membaca pemahaman dan metode Collaborative Learning. Kesimpulan tersebut adalah sebagai berikut:

a. Terjadi peningkatan kemampuan berbahasa Inggris khususnya kemampuan membaca teks diskriptif para siswa yang cukup signifikant setelah mendapatkan pembelajaran dengan menggunakan metode Collaborative Learning selama tujuh siklus dimana nilai rata-rata tes awal hanya 5,5 menjadi 7,5 pada tes akhir hingga ada peningkatan 2,0. Dengan kata lain Pelatihan Peningkatan Kemampuan Berbahasa Inggris dengan metode Collaborative learning pada siswa kelas 4 diniyah di Pondok Pesantren Al-Azhar Citangkolo Kota Banjar Berhasil.

b. Pada pelaksanaan penerapan metode Collaborative Learning yang berlangsung pada pengabdian hari kedua sampai ke delapan yang artinya ada tujuh siklus terjadi perubahan kebiasaan siswa yang tadinya cenderung ribut menjadi lebih teratur. Para siswa yang juga awalnya sangat tidak biasa bekerja sama pelan-pelan mulai biasa dan akhirnya sangat terampil bekerja sama. Siswa juga cenderung sangat akfit baik bertanya maupun dalam menyampaikan ide dan pendapat.

c. Peran guru/instruktur juga mengalami perubahan yang cukup signifikant jika di siklussiklus awal dia cenderung sangat dominan mengatur kelas, maka di siklus-siklus akhir sangat bebas karena dia berhasil mengaktifkan siswa dalam bekerjasama sehingga siswa cenderung mandiri tanpa banyak dibantu. 


\section{DAFTAR PUSTAKA}

Abdul dan Dian Andayani, Pendidikan Agama Islam Berbasis, Bandung : PT Remaja Rosdakarya, 2006.

Abdul Majid, Strategi Pembelajaran, Bandung: Rosdakarya, 2014.

Bambang, Setiyadi.2006. Teaching English As a Foreign language. Yogyakarta. Graha Ilmu.

Barkley, Elizabeth E. 2014. Collaborative Learning Techniques. Bandung NusaMedia.

Drs. Hasan Basri,M.Ag. Ilmu Pendidikan Islam (jilid II), (Bandung:

ANGKASA, 2009)

Elliot, J. 1991. Action Research for Educational Change. New York:Routledge.

Hammer, Jeremy, 2001. The Practice of English Language Teaching. Harlow. Longman.

Hopkins, D. 1993. A teachers` Guide to Classroom Research. Philadelphia:Open University Press.

Mohammad muchlis solichin, Masa Depan Pesantren, (Surabaya.

SALSABILA. 2013)

Muhaimin dkk, Strategi Belajar Mengajar Penerapannya Dalam Pengembagan Pendidikan Agama, Surabaya : CV Citra Media Karya Anak Bangsa, 1996.

Muhibbin Syah, Psikologi Pendidikan dengan Pendekatan Baru, Bandung : Rosdakarya, 1997.

Natawidjaja, R. 1997. Penelitian Tindakan Kelas. Jakarta. Dirjen Dikti Depdiknas.

Tarigan, H.G. 1993. Membaca: Sebagai Suatu Keterampilan Berbahasa. Bandung. Angkasa 